\title{
The Relationship Between Self-Esteem and Academic Achievement Among Addis Ababa University Undergraduate Psychology Students
}

\author{
Mulugeta Deribe Damota* \\ Department of Psychology, College of Education and Behavioral Studies, \\ Madda Walabu University, Bale Robe, Ethiopia \\ Eden Hussein Ibrahim \\ St Paul Hospital, Millennium Medical College, Department of Psychiatry, Addis Ababa, \\ Hailemariam Hailesillassie Woldemariam \\ Faculty of medical Science, Department of Psychiatry, Jimma University, Jimma, Ethiopia \\ Getahun Tibebu Kifle \\ Addis Ababa University, college of health science,school of medicine Department of Psychiatry, Addis Ababa
}

\begin{abstract}
The main purpose of the study was is to examine the relationship between self-esteem, gender, and academic achievement among Addis Ababa University Undergraduate psychology students. The study was conducted on 100 second and third year psychology students those gave their written consent. The pertinent data were collected by using Rosenberg self - esteem scale and the students' cumulative average grade point. The collected data were analyzed via independent T-tests, one way ANNOVA and Pearson correlation at alpha level 0.05 . The analysis result shows that there is statistically significant mean difference between self-esteem and mother and father education level (with $p$-value $=0.030$ and 0.001 for father and mother education level, respectively). The mean selfesteem score of students whose families are illiterate is greater than those students who came from college and above educated family. The mean self-esteem score of male students was higher than the mean score of female students ( $p$-value $<0.0001$; Mean $=21.32$ and 18.16 for male and female, respectively). However, there is no statistical significant difference between self-esteem academic achievement as well as place of residence. The study recommends that future studies should put effort to measure the significant relationship between self-esteem and academic achievement by including more variables, increasing the number of participants and by using longitudinal study design.
\end{abstract}

Keywords: Academic achievement, self esteem

DOI: $10.7176 / \mathrm{JEP} / 10-4-03$

\section{I.Introduction}

\subsection{BACKGROUND OF THE STUDY}

Self-esteem is the most extensively studied topic in psychology (Baumeister, 1993; Gebauer et al.,, 2008). From 1970 to 1990 the students' self-esteem was assumed by many researchers and practitioners as a critical aspect in the grades they obtain in the subject matters, in their relationships with their peers, and in their later success in life.

The term achievement refers to the degree or the level of success attainted in some specific school tasks especially scholastic performance, in this sense academic achievement means the attained ability to perform school tasks, which can be general or specific to a given subject matter. Academic achievement could be defined as selfperception and self-evaluation of one's objective academic success.

Findings across the world indicated that many researchers studied self-esteem in association with different factors (Anthony, Wood, \& Holmes, 2007); Self Esteem, Gender and Academic Achievement of Undergraduate Students ( Barry, Grafeman, Adler, \& Pickard, 2007; Denissen et al., 2008; Rubinstein, 2006)

As to the knowledge of the researchers of this paper, there is no study done on self-esteem with variables of academic achievement and gender among Addis Ababa university undergraduate psychology students.

Self-esteem continues to be one of the most commonly research concepts in the study of psychology because of its impact in different dimension of human life. The study of the relationship between self-esteem and academic achievement is documented in controversial idea on which one come first, which one is the result of the other. This study focuses on the relationship between self-esteem and academic achievement on Addis Ababa University psychology students with other dimensions like its relationship with gender, place of residence and family education. As to the investigators knowledge, there is no study done on the relationship between self-esteem, academic achievement, gender, place of residence, and family's educational background among undergraduate psychology students of Addis Ababa University. 


\subsection{The specific objective of the study is to:}

$>$ To examine the statistical difference between gender and self-esteem.

$>$ Investigate whether the students' self-esteem varies across place of residence of students.

$>$ To identify the relationship between self-esteem and academic achievement.

\section{Literature Review}

\subsection{The concept of Self-esteem}

For people of all ages, the development of full human potential is enhanced through high self-esteem. Many study results reported role of self-esteem in the person's overall development including personal and social responsibility, academic achievement (Redenbach, 1991).

Different scholars define self-esteem in different ways. Rosenberg (1965) defines the self-esteem in terms of "a stable sense of personal worth or worthiness".

In Maslow's (1987) hierarchy of needs, he emphasized on self-esteem in his theory. He introduced two different types of esteem: "the need for respect from others and the need for self-respect, or inner self-esteem. Respect from others entails recognition, acceptance, status, and appreciation, and was believed to be more fragile and easily lost than inner self-esteem".

According to Tam \& Fatimah Yusooff (2009), self-esteem is observed to be determined both by the degree of inconsistency between a person's goals and the accomplishments, and by the degree of emotional support perceived from parents and peers. Self-esteem would also develop out of a person's experience with person will see himself or herself as failing to live up to the own goals or values and thus result in a lower self-esteem.

\subsection{Self-Esteem and Academic Achievement}

In the relationship between self-esteem and academic achievement, research findings across the world indicated contradictory findings about whether self-esteem is resulted from academic achievement or vice versa. On the one hand, several findings report the importance of academic achievement on raising students' self-esteem.

According to Malbi \& Reasoner (2000), level of academic grades enhances the person's worthiness and competence. Similar findings reported that high self-esteem is partly the result of good school performance. Students with a low level of achievement possess a self-esteem that is considerably lower than that of students with a high level of achievement (Alves-Martins et al., 2002). Students in a competitive and grade-conscious educational institution, they are constantly reminded of the importance of their grades, own performances, and their personal determinations of success or failure eventually shapes their self-esteem levels (Purkey, 1970). Students with high cumulative GPA were found to have higher levels of self-esteem (Bahman et al., 2011).

A study done by Andrea Chan Huan Wen (2011) among 100 undergraduate psychology students by using Rosenberg Self-esteem Scale indicated that students' with higher academic performance will have a higher selfesteem.

On the other hand, in many study investigating the relationship between self-esteem and academic achievement, high self-esteem was found to facilitate academic achievement (Habibollah Naderi et. al, 2009; Owens, Mortimer \& Finch, 1996). They stated that self-esteem has a positive effect on grades. That is self-esteem is assumed as a possibility reason for high academic achievement where good academic grades enhance one's sense of worthiness and competence.

However, there are also studies indicating that there is inverse relationship between self-esteem and academic achievement. In a study done by Rozumah et al., 2009), students with lower self-esteem performed better in their academics. In their longitudinal study, Pullman and Allik(2008) shown that students with higher academic performance are more self-critical compared to students with moderate academic performance.

However, other longitudinal study findings indicated that there is no significant relationship existed between self-esteem and academic achievement (Maruyama et al., 1981; Yogev and Ilan, 1987). They reveal that self esteem and achievement were not "causally" related to each other.

\subsection{Self-Esteem and Gender}

Study so far done indicated contradictory findings .On the one hand, studies conducted by many researchers reported that their finding indicated that male students scored significant higher on self-esteem than female students (Andrea Chan Huan Wen, 2011; Aunola, Stattin \& Nurmi, 2000; McMullin and Cairney, 2004; Rabbins et al., 2002). Their findings reported that low self-esteem was found to be more common in girls than boys. On the other hand, however, a study done by Habibollah Naderi et al. (2009) shows that female students were found to score higher in self esteem than male students.

There are also some studies that did not show any significant difference of self-esteem scores by gender (Patton, Bartrum and Creed, 2004; Rozumah Baharudin \& Sheereen Zulkefly, 2009). 


\subsection{Parents' education and self-esteem}

There are studies indicating whether or not student's self-esteem is impacted by parent's educational level. A research done by Scott (2004) revealed that the level of education is positively correlated to self-esteem. The researcher stated that parents who themselves have had the benefits of higher education can pass on values concerning the importance of learning to their children. This idea is strengthened by another study finding showing that there is a significant positive correlation between parents' education and students' self-esteem (Andrea Chan Huan Wen, 2011).

However, in another study, parental education is negatively related to adolescents' self-esteem (Ross \& Broh, 2000). This is because well-educated parents expect more from their children, so that at the same level of academic achievement, adolescents with well-educated parents do not feel as good about themselves as do those whose parents are less educated (Ross \& Broh, 2000).

\subsection{Place of Residence and self-esteem}

It is obviously known that for the proper development of child, organized and effective environment in the family and his social world are pre-requisites. This also supported by research finding that environment plays important role in determining the course of adolescents' self-esteem (DuBois,et al., 2002).

Studies done by Devi and Prashani(2004) shows that students grew in rural area face more social and cultural deprivation as compared to urban students.

They also indicated that student who came from urban environments were found to be superior in their selfesteem scores as compared to the students who were from the urban environments. However, a research done by Shobhna Joshi and Rekha Srivastava (2009) with sample of 400 adolescents found that Self-esteem was not significantly different among rural and urban students. This study finding rejected the hypothesis that urban adolescent has higher level of self-esteem than rural adolescents.

\subsection{Conceptual Framework}

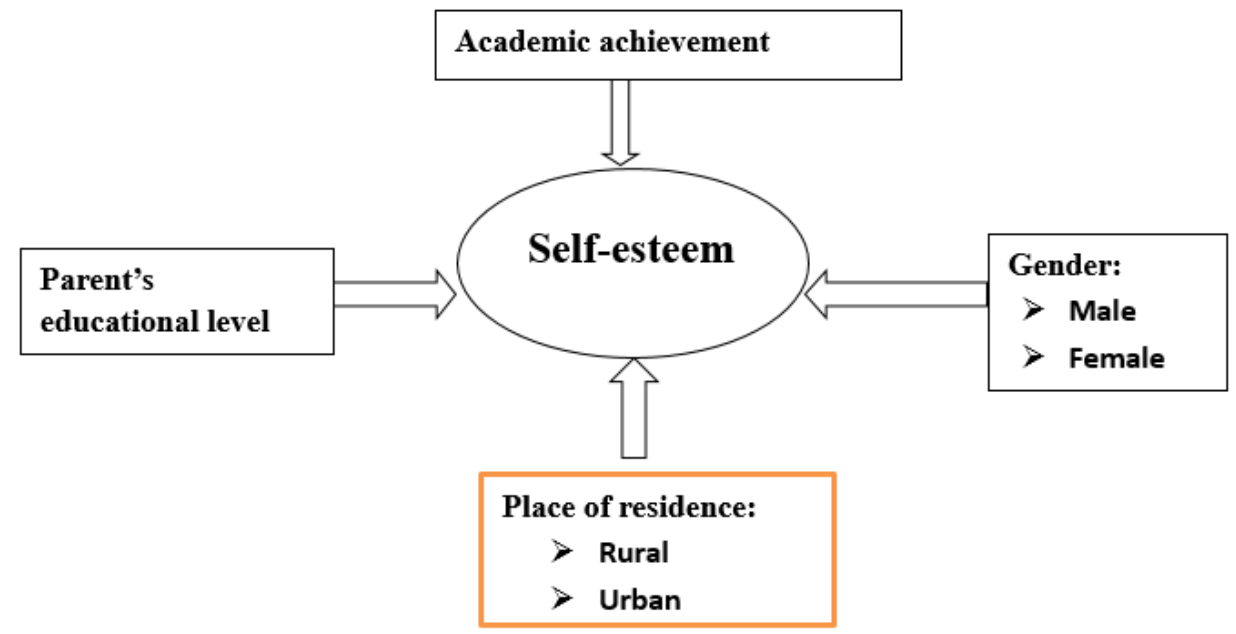

\section{III.Methods and Materials}

\subsection{Study area and period}

The study was conducted in Addis Ababa University in December 2012. Addis Ababa University is one the Ethiopian higher institution which is located in the capital city of Addis Ababa.

\subsection{Study Design}

A cross-sectional study design was used among Addis Ababa University undergraduate psychology (AAUPSY) students of 2012. The study employed a self-administer questionnaire consisting of Rosenberg self-esteem scale and the respondent's demographic characteristics.

\subsection{Source \& Study population}

The source and study populations of this study were 100 AAUPSY undergraduate students of 2012.

\subsection{Inclusion criteria:}

All undergraduate $2^{\text {nd }}$ and $3^{\text {rd }}$ year Psychology students who filled the written consent 


\subsection{Exclusion criteria:}

$1^{\text {st }}$ year undergraduate Psychology students and Students who did not fill the written consent

\subsection{Measuring instrument and data collection procedure}

The study used a self-administered Questionnaire consisting of Rosenberg Self-esteem scale (RSES; 10 -items), demography characteristics of respondents. The RSES scale measures self-esteem using a 4 (four) -point Likert scale $(1=$ strongly agree, $2=$ Agree, $3=$ disagree, $4=$ strongly disagree $)$ with questions about students attitude.

The data were collected by the researchers. The data collectors distributed the self-administered questionnaires among the study participants.

Questions that rose while students were filling the questionnaire were addressed at the spot by the data collectors. The data collectors cross checked whether or not the respondents filled the questionnaire properly. They assured that the students' participation would have no influence on their academic performance as the data collected in anonymity and that data will be securely stored on locked premises in the department of Psychology. To avoid peer group influence, the students were told to avoid discussion their statements among themselves.

\subsection{Data Analysis}

Data was analyzed to generate descriptive statistics: means, frequency, percentages and standard deviations, using statistical package for social sciences (SPS version 20). Other statistical methods such as Independent samples Ttests, one way ANOVA and Pearson correlations methods were used to analysis the SPPS entered data. The data also analyzed with $95 \%$ confidence interval.

\subsection{Data quality assurance}

To keep the quality of the study's data, the data collectors checked whether the eligible participants filled the questionnaires properly or not. The investigators used double data entry system during data entry. The data cleaning and processing strictly was done before analysis.

\subsection{Ethical Considerations}

The ethical approval was obtained from the Psychology Department of Addis Ababa University. Written informed consent also obtained from the study participants. The study on the relationship between Self-esteem and academic achievement would have no influence on the academic performance of the study units/cases. The data collection did not reveal the eligible participants names. An information sheet was attached with each questionnaire to provide study details, rights of the participants and suggesting that filling the questionnaire implies informed consent. Participants had been given the right to withdraw from the study at any stage of the research.

\subsection{Limitation of the study}

The prominent limitations of the study were that

$>$ Difficult to generalize the results to other populations in other settings due to mere focus of all $2^{\text {nd }}$ and $3^{\text {rd }}$ year under graduate psychology students

$>$ The number of male and female respondents were not equal to identify the significance difference of gender

$>$ Unable to include first year students due to the absence of Cumulative Average Grade point (CGPA).

$>$ The study used one time data collection.

\section{IV.Result/Finding}

For the purposes of this study, Academic achievement was measured through the Cumulative Grade point Average (CGPA), which was computed based on participants' grades. The CGPA is calculated by dividing the total amount of grade points earned by the total amount of credit hours attempted. In this study, we used four-mark grading system ranging from 1 (very weak) to 4 (very good) which was also used in previous researches (Habibollah. Naderi et al.,2009).

Table1. CGPA of the respondents

\begin{tabular}{|l|l|}
\hline \multicolumn{1}{|c|}{ Cumulative Grade Point Average (CGPA } \\
\hline \multicolumn{1}{|c|}{ Result } & Level \\
\hline $3.51-4.0$ & 4 \\
\hline $3.1-3.5$ & 3 \\
\hline $2.51-3.0$ & 2 \\
\hline $0-2.5$ & 1 \\
\hline
\end{tabular}


Table2. Mean and standard deviation of self-esteem +Independent variables

\begin{tabular}{|c|c|c|c|c|}
\hline Independent Variable & Category & $\begin{array}{l}\text { Frequency } \\
(\mathrm{N})\end{array}$ & Mean & $\begin{array}{l}\text { Standard } \\
\text { deviation }\end{array}$ \\
\hline \multirow[t]{3}{*}{ Sex } & Male & 57 & 21.32 & 3.18 \\
\hline & Female & 43 & 18.16 & 4.64 \\
\hline & Total & 100 & & \\
\hline \multirow[t]{3}{*}{ Place of residence } & Urban & 74 & 19.95 & 4.06 \\
\hline & Rural & 26 & 20.00 & 4.53 \\
\hline & Total & 100 & & \\
\hline \multirow{6}{*}{$\begin{array}{l}\text { Father } \\
\text { background }\end{array}$} & Illiterate & 16 & 22.56 & 4.34 \\
\hline & $\begin{array}{l}\text { not completed elementary } \\
\text { school }\end{array}$ & 15 & 19.93 & 2.87 \\
\hline & elementary school completed & 25 & 20.04 & 3.62 \\
\hline & secondary school completed & 12 & 20.33 & 2.19 \\
\hline & college and above & 32 & 18.47 & 4.98 \\
\hline & Total & 100 & & \\
\hline \multirow{6}{*}{$\begin{array}{ll}\text { Mother } & \text { Educational } \\
\text { background } & \end{array}$} & Illiterate & 25 & 21.00 & 4.10 \\
\hline & $\begin{array}{l}\text { not completed elementary } \\
\text { school }\end{array}$ & 14 & 21.86 & 2.60 \\
\hline & elementary school completed & 25 & 20.04 & 3.09 \\
\hline & secondary school completed & 13 & 21.15 & 4.78 \\
\hline & college and above & 23 & 16.91 & 4.33 \\
\hline & Total & 100 & & \\
\hline \multirow[t]{4}{*}{ Academic achievement } & $0-2.50$ & 42 & 19.98 & 3.75 \\
\hline & $2.51-3.00$ & 35 & 20.09 & 4.40 \\
\hline & $3.10-3.50$ & 16 & 18.56 & 3.67 \\
\hline & $3.51-4.00$ & 7 & 22.43 & 5.86 \\
\hline
\end{tabular}

As table 2 above shows, the total respondents participated in this study were 100 . Of them 57 were males and the remaining 43 were females. The mean age of the total population study is 22.63 with standard deviation of 4.23 which is ranged from 19 to 38 . Mean age for female students was 21.31 and for male.

Table 3. Independent T-tests of the Parameters= self-esteem + gender; self-esteem + place of residence

\begin{tabular}{|c|c|c|c|c|c|c|c|c|c|c|c|}
\hline & & & \multicolumn{2}{|c|}{$\begin{array}{l}\text { Levene's Test } \\
\text { for Equality } \\
\text { of Variances }\end{array}$} & \multicolumn{7}{|c|}{ t-test for Equality of Means } \\
\hline & & & \multirow[t]{2}{*}{ F } & \multirow[t]{2}{*}{ Sig. } & \multirow[t]{2}{*}{$\mathrm{T}$} & \multirow[t]{2}{*}{ Df } & \multirow[t]{2}{*}{$\begin{array}{l}\text { Sig. } \\
(2 \text {-tail } \\
\text { ed) }\end{array}$} & \multirow[t]{2}{*}{$\begin{array}{c}\text { Mean } \\
\text { Difference }\end{array}$} & \multirow{2}{*}{$\begin{array}{l}\text { Std. } \\
\text { Error } \\
\text { Differen } \\
\text { ce }\end{array}$} & \multicolumn{2}{|c|}{$\begin{array}{l}95 \% \text { Confidence } \\
\text { Interval of the } \\
\text { Difference }\end{array}$} \\
\hline & & & & & & & & & & Lower & Upper \\
\hline \multirow{2}{*}{$\begin{array}{l}\text { Self-esteem+ } \\
\text { gender }\end{array}$} & \multirow{2}{*}{$\begin{array}{l}\text { Self-este } \\
\text { em }\end{array}$} & $\begin{array}{ll}\text { Equal } & \text { variances } \\
\text { assumed } & \end{array}$ & \multirow[t]{2}{*}{4.162} & \multirow[t]{2}{*}{.044} & \multirow[t]{2}{*}{4.027} & \multirow[b]{2}{*}{70.364} & \multirow[t]{2}{*}{.000} & \multirow{2}{*}{$\begin{array}{l}3.15300 \\
3.15300\end{array}$} & \multirow{2}{*}{$\begin{array}{l}.78288 \\
82402\end{array}$} & \multirow{2}{*}{$\begin{array}{l}1.59940 \\
1.50970\end{array}$} & \multirow{2}{*}{$\begin{array}{l}4.70660 \\
4.79630\end{array}$} \\
\hline & & $\begin{array}{l}\text { Equal variances not } \\
\text { assumed }\end{array}$ & & & & & & & & & \\
\hline \multirow[t]{2}{*}{$\begin{array}{l}\text { Self-esteem } \\
\text { environment }\end{array}$} & \multirow[t]{2}{*}{$\begin{array}{l}\text { Self-este } \\
\text { em }\end{array}$} & $\begin{array}{l}\text { Equal variances } \\
\text { assumed }\end{array}$ & \multirow[t]{2}{*}{.103} & \multirow[t]{2}{*}{.748} & \multirow{2}{*}{$\begin{array}{l}-.057 \\
-.054\end{array}$} & 98 & .955 & -.05405 & .95393 & -1.947 & 1.8389 \\
\hline & & $\begin{array}{l}\text { Equal variances not } \\
\text { assumed }\end{array}$ & & & & 40.048 & .957 & -.05405 & 1.00525 & -2.0856 & 1.9775 \\
\hline
\end{tabular}

Table 3. Shows independent sample T-test was conducted to see mean difference between students' selfesteem and gender and their respected place of residence (where they grow). Self-esteem is significantly different by gender among the study respondents (with $\mathrm{p}$-value $<0.0001 ; \mathrm{f}=4.16$; $\mathrm{DF}=98$ ). The mean self-esteem score of male students was higher than the mean score of female students (Mean $=21.32$ and 18.16 for male and female, respectively). But the independent t-test shows that self-esteem score difference was not significant among students who grew in rural areas and urban areas ( $p$-value=0.955; Mean of urban=19.95, Mean rural=20.00). 
Table 4. One way ANOVA tests on Parameter of Self-esteem + family's educational Background; selfesteem+ academic achievement

\begin{tabular}{|c|c|c|c|c|c|c|}
\hline Variables & & $\begin{array}{l}\text { Sum of } \\
\text { Squares }\end{array}$ & Df & Mean Square & $\mathrm{F}$ & Sig. \\
\hline $\begin{array}{l}\text { Father Educational } \\
\text { background }\end{array}$ & $\begin{array}{l}\text { Between } \\
\text { Groups } \\
\text { Within } \\
\text { Groups } \\
\text { Total }\end{array}$ & $\begin{array}{r}181.37 \\
1534.46 \\
1715.84\end{array}$ & $\begin{array}{l}95 \\
99\end{array}$ & $\begin{array}{l}45.34 \\
16.15\end{array}$ & 2.81 & 0.030 \\
\hline $\begin{array}{l}\text { Mother Educational } \\
\text { background }\end{array}$ & $\begin{array}{c}\text { Between Groups } \\
\text { Within Groups } \\
\text { Total }\end{array}$ & $\begin{array}{l}309.64 \\
1406.19 \\
1715.84\end{array}$ & $\begin{array}{l}4 \\
95 \\
99\end{array}$ & $\begin{array}{l}77.41 \\
14.80\end{array}$ & 5.23 & 0.001 \\
\hline $\begin{array}{l}\text { Academic } \\
\text { achievement }\end{array}$ & $\begin{array}{c}\text { Between Groups } \\
\text { Within Groups } \\
\text { Total }\end{array}$ & $\begin{array}{l}74.46 \\
1641.37 \\
1715.84\end{array}$ & $\begin{array}{l}3 \\
96 \\
99\end{array}$ & $\begin{array}{l}24.82 \\
17.09\end{array}$ & 1.45 & 0.23 \\
\hline
\end{tabular}

As it is indicated in table 4, one way ANOVA analysis was used to see whether there is a mean difference among the respondents' self-esteem scores based on the family's educational background and academic achievement. Thus, the analysis result shows that there is statistically significant mean difference between selfesteem and mother and father education level (with $\mathrm{df}=4, \mathrm{~F}=2.81$ and 5.23, $\mathrm{p}$-value $=0.030$ and 0.001 for father and mother education level, respectively). Particularly, the self-esteem mean score of students whose families are illiterate is greater than those students who came from college and above educated family (father illiterate mean=22.56 and college \&above mean=18.47; mother illiterate mean=21.00 and college \&above mean=16.91). The one way ANNOVA analysis results indicated that there is no significant mean difference between self-esteem and academic achievement with p-value of 0.23 and F- value of 1.45.

Table 5. correlations between self -esteem and independent variables(place of residence, gender and family education background )

\begin{tabular}{|c|c|c|c|c|c|c|}
\hline & & $\begin{array}{l}\text { cumulative grade } \\
\text { point of students }\end{array}$ & $\begin{array}{l}\text { sex identity } \\
\text { of student }\end{array}$ & $\begin{array}{l}\text { Place of } \\
\text { residence }\end{array}$ & $\begin{array}{c}\text { father } \\
\text { educational } \\
\text { background }\end{array}$ & $\begin{array}{c}\text { mother } \\
\text { educational } \\
\text { background }\end{array}$ \\
\hline \multirow{3}{*}{$\begin{array}{l}\text { Self- } \\
\text { esteem }\end{array}$} & $\begin{array}{c}\text { Pearson } \\
\text { Correlation }\end{array}$ & .03 & $-.38^{* *}$ & .01 & $-.29^{* *}$ & $-.33^{* *}$ \\
\hline & Sig. (2-tailed) & .76 & .000 & .955 & .004 & .001 \\
\hline & $\mathrm{N}$ & 100 & 100 & 100 & 100 & 100 \\
\hline
\end{tabular}

**. Correlation is significant at the 0.01 level (2-tailed).

As it is shown in table 4 above, self-esteem is significantly related with variables such as gender and family educational background( $\mathrm{r}=-0.38$ and $\mathrm{r}=-0.29,-0.33$, respectively). On the other hand, self-esteem has no relationship between academic achievement and place of residence ( $\mathrm{r}=0.03$ and 0.01 , respectively).

\section{DISCUSSION}

The purpose of this study was to determine if a relationship exists between self-esteem and the academic achievement, gender and family educational background. Findings of this study showed that male students were higher in their self-esteem scores than females which is consistent also with majority of earlier findings (Andre et al., 2011; Aunola et al., 2000; Dubois et al., 2002; McMullin and Cairney, 2004; Rabbins et al., 2002). But this finding is contradicted with the study results done by Habibollah Naderi et al. (2009) found that females were higher in their self-esteem than boys.

In earlier studies it is reported that there is significant relationship between academic achievement and selfesteem indicating that these two variables predict one another (Andrea et al.,, 2011; Bahman et al.,, 2011; Habibollah Naderi et al., 2009; Malbi \& Reasoner, 2000; Owens, Mortimer \& Finch, 1996). In this study, however, the one way ANNOVA and Pearson correlation analysis results indicated that there was no relationship between academic achievement and self-esteem among the study respondents which is also consisted with longitudinal research results done by Maruyama et al., 1981; Yogev and Ilan, 1987).

In this study, the investigators found that there is significant relationship between self-esteem and family's educational levels. The Pearson correlation analysis also shows that the relationship between self-esteem and family education is negative. Furthermore, the mean self-esteem score of students whose families are illiterate were found to have higher self-esteem scores than those students from college and above educated families which is consistent with previous study results((Ross \& Broh, 2000). They argued that the educated families' insist to make their adolescents academically competent, has negative impact on students' self-esteem level.

Previous research reported that students grown from urban areas have higher scores than rural areas (Devi 
and Prashani, 2004). But in this study, we found that self-esteem was not significantly different among the studied urban and rural students which are supported by the research results done by Shobhna Joshi and Rekha Srivastava (2009).

\section{VI.Conclusion and Recommendation}

\subsection{Conclusion}

The main findings of this study were that self-esteem has no relation with academic achievement, and place of residence. But the self-esteem is significantly related with gender and students' family educational background.

\subsection{Recommendation}

The researchers forwarded the following implications.

The findings from this study has important implications for those students and others (postgraduate, diploma, high school) students.

Examination that improvement of self-esteem in university, is disquieting to review in the findings that no improvement in self-esteem scores was studied, indeed, there was a non-significant differences /related in selfesteem scores and other variables (academic achievement, place of residences). However, future studies should effort to better separate discrete abilities and measure their significantly-relation to academic achievement by including several variables, increasing the number of participants and using longitudinal study design.

\section{Acknowledgements}

This study was conducted for the partial fulfillment of the course Advanced Statistics and Research Methods. We would like to express our deepest gratitude to our instructor Dr. Alemayehu Bekele for his initiation of doing this research and his constructive advice.

Next our thanks go to the Department of psychology for its permission to conduct study on their students The last but not the least thank is for our respondent for their willingness to participate in this study

\section{References}

$>$ Lawrence, S. et al. (2001). Persistence of Web References in Scientific Research. Computer. 34, 26-31. AlvesMartins, M., Peixoto, F., Gouveia-Pereira, Amaral, V. \& Pedro, I. (2002). Self-esteem and Academic Achievement among Adolescents. Educational Psychology, 22(1), 51- 62. http://staff.bath.ac.uk/ecsjgs/Research/Child\%20Development/References/0V56YEM 5M0NTX6V8.pdf

$>$ Andrea Chan Huan Wen (March 2011). A Study of Self-Esteem among Utar Psychology Students.

$>$ Anthony, D. B., Wood, J. V., \& Holmes, J. G. (2007). Testing sociometer theory: Self-esteem and the importance of acceptance for social decision-making. Journal of Experimental Social Psychology, 43(3), 425432.

$>$ Aunola, K., Stattin, H., \& Nurmi, J-E. (2000). Adolescents' Achievement Strategies, School Adjustment, and Eternalizing and Internalizing Problem Behaviors. Journal of Youth and Adolescence, 29(3), 289-306.

$>$ Bahman Kord Tamini and Roya Valibeygi (2011). The Impact of Gender, Age and Academic Branch on SelfEsteem of Students. Journal of Basic and AppliedScientific Research: J. Basic. Appl. Sci. Res., 1(9)1065-1069

$>$ Barry, C. T., Grafeman, S. J., Adler, K. K., \& Pickard, J. D. (2007). The relations among narcissism, selfesteem, and delinquency in a sample of at-risk adolescents. Journal of Adolescence, 30(6), 933-942.

$>$ Baumeister, R. F. (1993). Understanding the inner nature of self esteem. In R.F. B a u m e i s t e r (Ed.), Self - esteem: the puzzle of low self regard (pp. 201-218). New York: Plenum.

$>$ Denissen, J. J. A., Penke, L., Schmitt, D. P., \& van Aken, M. A. G. (2008). Self-Esteem Reactions to Social Interactions: Evidence for Sociometer Mechanisms across Days, People, and Nations. Journal of Personality and Social Psychology, 95(1), 181-196.

$>$ Devi, T. K. \& Prasanti (2004). Self- concept of adolescents in urban and rural areas. Indian Psychological Review, 62, 202-206

$>$ DuBois, D. L., Burk- Braxton, C., Swenson,L. P., Tevendale, H. D., \& Hardesty, J. L., (2002). Race and gender influences on adjustment in early adolescence: Investigation of an iterative model. Child development, 73, 1573-1592.

$>$ Gebauer, J. E., Riketta, M., Broemer, P., \& Maio, G. R. (2008). "How much do you like your name?" An implicit measure of global self-esteem. Journal of Experimental Social Psychology, 44(5), 1346-1354.

$>$ Habibollah Naderi et al.,(2009). Self-esteem, Gender and Academic Achievement of Undergraduate Students. American Journal of Scientific Research, 3, 26-37. http://www.eurojournals.com/ajsr_3_03.pdf

$>$ Malbi, R. S., \& Reasoner, R. W. (2000). Self-Esteem, Enhancing. Kuala Lumpur: Self-Esteem Seminars Sdn. Bhd.

$>$ Maruyama, G. M., Rubin, R. A., \& Kingsbury, G. G. (1981). Self-esteem and educational achievement: Independent constructs with a common cause? Journal of Personality and Social Psychology, 40(5), 962-975. 
$>$ Maslow A. H. (1987). Motivation and Personality (3rd ed.). New York: Harper \& Row.

$>$ McMullin, J. A., and Cairney, J. (2004). Self-esteem and the intersection of age, class, and gender. Journal of Aging Studies, 18 (1), 75-90.

$>$ Owens, T. J., Mortimer, J. T., \& Finch, M. D. (1996). Self-Determination as a Source of Self- Esteem in Adolescence. Social Forces, 74(4), 1377-1404.

$>$ Patton, W., Bartrum, D. A., \& Creed, P. A. (2004). Gender differences for optimism, self-esteem, expectations and goals in predicting career planning and exploration in adolescents. International Journal for Educational and Vocational Guidance, 4 (3), 193-209.

$>$ Piyavhatkul N et al (2011). Validity and reliability of the Rosenberg Self-Esteem Scale-Thai version as compared to the Self-Esteem Visual Analog Scale. Med Assoc Thai. 94(7):857-62.

$>$ Pullmann, H., \& Allik, J. (2008). Relations of academic and general self-esteem to school achievement. Personality and Individual Differences, 45(6), 559-564.

$>$ Purkey, W. W. (1970). Self-concept and school achievement. Englewood Cliffs, NJ: Prentice Hall. Robinson, J. P., \& Shaver, P. R. (1973). Measures of social psychological attitudes. Ann Arbor, MI: Institute for Social Research.

$>$ Redenbach, S. (1991). Self-Esteem, the Necessary Ingredient for Success. USA: Esteem Seminar Programs and Publications.

$>$ Robins, R. W., Trzesniewski, K. H., Tracy, J. L., Gosling, S. D., \& Potter, J. (2002). Global selfesteem across the life span. Psychology and Aging, 17, 423-434.

$>$ Rosenberg, M. (1965). Society and the Adolescent Self-image. Princeton, NJ: Princeton University Press.

$>$ Ross, C. E., \& Broh, B. A. (2000). The Roles of Self-Esteem and the Sense of Personal Control in the Academic Achievement Process. Sociology of Education, 73(4), 270-284.

$>$ Rozumah Baharudin \& Sheereen Zulkefly (2009). Relationship with Father and Mother, Self-Esteem and Academic Achievement. American Journal of Scientific Research, 6, 86-94. http://www.eurojournals.com/ajsr_6_09.pdf

$>$ Scott, J. (2004). Family, Gender, and Educational Attainment in Britain: A Longitudinal Study. Journal of Comparative Family Studies, 35(4), 565-589.

$>$ Shobhna Joshi and Rekha Srivastava (October 2009). Self-esteem and Academic Achievement of Adolescents. Journal of the Indian Academy of Applied Psychology Vol. 35, Special Issue, 33-39.

$>$ Tam, C. L., \& Fatimah Yusooff. (2009). The Effects of Family Functioning on Self-Esteem of Children. European Journal of Social Sciences, 9(4), 643-650. http://www.eurojournals.com/ejss_9_4_11.pdf

$>$ Yogev, A. \& Ilan, Y. (1987). Does self-esteem affect educational aspirations? Urban Education, 22(2), 182202 . 